mediastudies.press • Social Media \& the Self: An Open Reader

\title{
The I in the Internet
}

\author{
Jia Tolentino
}

Published on: Feb 19, 2019

License: Creative Commons Attribution 4.0 International License (CC-BY 4.0). 
IN THE BEGINNING the internet seemed good. "I was in love with the internet the first time I used it at my dad's office and thought it was the ULTIMATE COOL," I wrote, when I was ten, on an Angelfire subpage titled "The Story of How Jia Got Her Web Addiction." In a text box superimposed on a hideous violet background, I continued:

But that was in third grade and all I was doing was going to Beanie Baby sites. Having an old, icky bicky computer at home, we didn't have the Internet. Even AOL seemed like a far-off dream. Then we got a new top-o'-the-line computer in spring break '99, and of course it came with all that demo stuff. So I finally had AOL and I was completely amazed at the marvel of having a profile and chatting and IMS!!

Then, I wrote, I discovered personal webpages. (“I was astonished!”) I learned HTML and "little Javascript trickies." ...

\section{continue reading}

\section{OUTBOUND LINK}

"The I in the Internet" (Jia Tolentino, CCCB Lab, February 19, 2020)

FREE ACCESS 